臨

床

凍瘡様皮疹を主徵とした本態性 IgA cryoglobulin 血症

\author{
京都府立医科大学公䒯衛生 \\ 山口 希॰ 川井啓市 \\ 京都府立医科大学皮庙科 \\ 加賀美 潔 \\ 京都府立医科大学第三内科 \\ 安芸 宏信 \\ 京都大学医学部第一内科 \\ 加納 正
}

\title{
A CASE OF IDIOPATHIC MONOCLONAL IgA CRYOGLOBULINEMIA
}

Nozomi Yamaguch, MD, and Keiichi KawaI, MD

Department of Preventive Medicine, Kyoto Prefectural University of Medicine, Kyoto

Kiyoshi Kagami, MD

Department of Dermatology, Kyoto Prefectural University of Medicine, Kyoto

Hironobu Akr, MD

The Third Department of Internal Medicine, Kyoto Prefectural University of Medicine, Kyoto

Tadashi Kano, MD

The First Department of Internal Medicine, Kyoto University, Kyoto

\begin{abstract}
槽要 Cryoglobulinにかんする知見は次第に集積されつつある. IgG, IgA, IgMの単独あるいは混合型 cryoglobulink加えてBence Jones蛋白から成るcryoglobulinが知られているが，なかですIA単独から 成るcryoglobulinはBence Jones cryoglobulinとならんで極めて少なく，これまでと 5 例の報告をみる

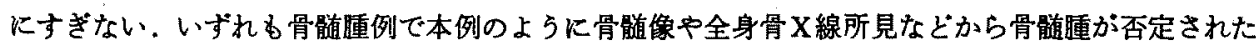
idiopathic cryoglobulin血症に属する例は未だ報告がなく，本邦初の報告例と思ら，症例は65才，女 性.約 6 年前から冬期になると治療に抗する頑固な凍痹，紅斑，水疱などをとくに皮唐露出部(手足， 顔面，耳染など）に生し，夏期には消失する，血清蛋白分画で $\beta$ 領域にIgA-L型M成分が認められ， $4^{\circ} \mathrm{C}$ 内に保存された血清のgel化により cryoglobulinの存在が碓認された。精製の結果, IgA単独から

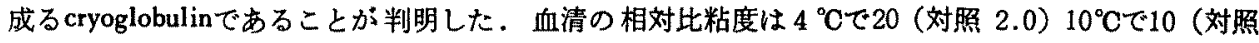
1.8）を示し，超遠心分析では $6.2 \mathrm{~S} ， 9.3 \mathrm{~S} ， 13.7 \mathrm{~S}$ Kpeakを認め，2，3 分子重合したpolymer型 IgAであることを確認した．この精製cryogelにはりウマチ因子活性や抗免疫グロブリン活性などは

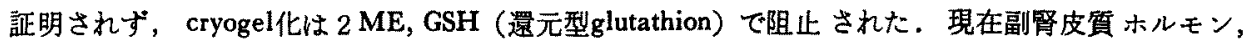
GSH㑉の使用により自覚症状, 皮疹, 血清相対比粘度ともに著明に改善されつつあり，経過観察中で ある。
\end{abstract}

[昭51年 6 月 30 日受稿] 


\section{緒言}

血清が寒冷条件で沈降ないしgel化し，そのコ ロイド可溶性が変化するるのとしてcryoglobulin が知られている，最初の報告はWintrobeらの骨䯣 畽例》で, Lernerらが紫斑病例てで同樣の蛋白をみ い出しcryoglobulin と命名 した ${ }^{2)}$. cryoglobulinの 寒冷沈降は保存血清の注意深い観察によつてしば しば検出される現象で，多くの疾患に合併する。 最も頻度の高い疾患は多発性骨髄腫括よびその類 縁疾患で, そのcryoglobulinの組成はいわゆる単 クローン性免疫 グロブリンから成つている。一 方, 肝硬変, 悪性リンパ腫, SLE, RA, Sjögren症 候群などに検出されるcryoglobulinは混合型が希 でなく，ときには補体成分 $\alpha_{2}$-macroglobulin， $\beta$-lipoproteinなどを含む例もあり混合型cryoglobulinと呼ばれ，種々の組み合せが知られてい る. 最近ではこのようなcryoglobulinはimmune complex diseasesの一つとして解釈されている. 著者らは過去 6 年間にわたる難治性のpernio様皮 膚症状を冬期寒冷時期にのみ訴点, 治療に用いた GSH製剂（還元型glutathion）に極めてよく反応 した本態性IgA cryoglobulin血症の 1 例を経験 L. たので報告する．われわれの調べた範囲では本態 性IgA cryoglobulinの報告は本邦初のものであ る.

\section{症 例}

患者：65才，女性.

主訴：凍瘡様皮疹.

家族歴：5女に冬期に出現する難治性凍瘡様 皮疹を認める. 父は胃潰瘍, 母は肉腫で死亡して いる.

既往歴：幼少時から痐瘡が出来やすい体質で あつたが， 6 年前までは異常を感じることなく生 活している.

現病歴：約 6 年前から冬期になると顔面, 耳 杂，手足背などの皮膚の露出部位に図 1 亿示す凍 瘡様皮疹を認めるようになり皮膚科で副腎皮質ホ ルモン軟膏療法を試みていた。著明な癌痒感と軽 度の知覚異常を訴えている。血液検査を受け，血

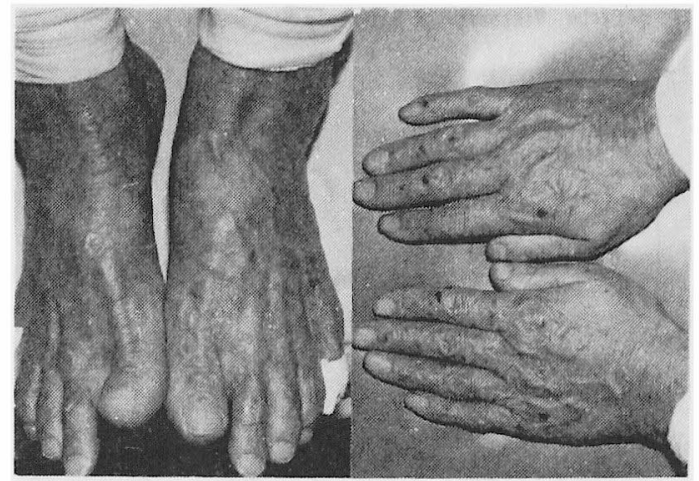

図 1，足背，手背に凍鹰様皮疹をみとめる。水疮形 成，出血が認められる。

清蛋白分画の $\beta$ 領域に少量のM成分が検出され， $4{ }^{\circ} \mathrm{C}$ 冷蔵庫内に保存された血清りgel化により cryoglobulin血症の疑いがもたれ精査をはじめた。

外来受診時現症：身長 $153 \mathrm{~cm}$, 体重 $47 \mathrm{~kg}$, 体 温 $36.5^{\circ} \mathrm{C}$, 脈拍70/分, 血圧 $126 / 70 \mathrm{~mm} \mathrm{Hg}$ であり, 顔面, 耳氺, 手背から前腕, 足背から膝関節部に かけての皮膚露出部に瘙痒感の強い凍瘡様皮疹, 水疮, 小出血を認め, 治癒部位には軽度の色素沈 着を残していた，躯幹には皮膚病変は全く観察さ れなかつた，結膜に貧血，黄疾の所見はなく，両 眼に初期老人性白内障を認めるが眼底に出血斑, 洀痕，血管の怒脹などの異常はなかつた，甲状腺 腫, 表在リンパ節腫大は認められず, 胸部打聴診 所見にも異常はなかつた，腹部所見にも特記すべ き異常は認められず, 手掌の軽い知覚異常以外に 神経学的異常所見もみい出せなかつた。

検査成績：一般臨床検査成績を表 1 亿示す。

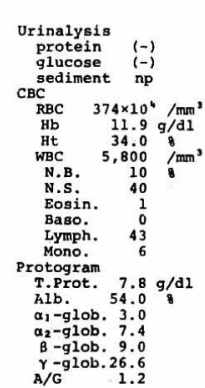

\section{表 1 ，臨床検査成樍}
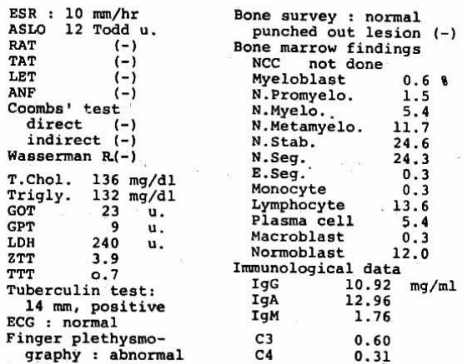
Serum Viscosity ( Ostwald's Viscometer)

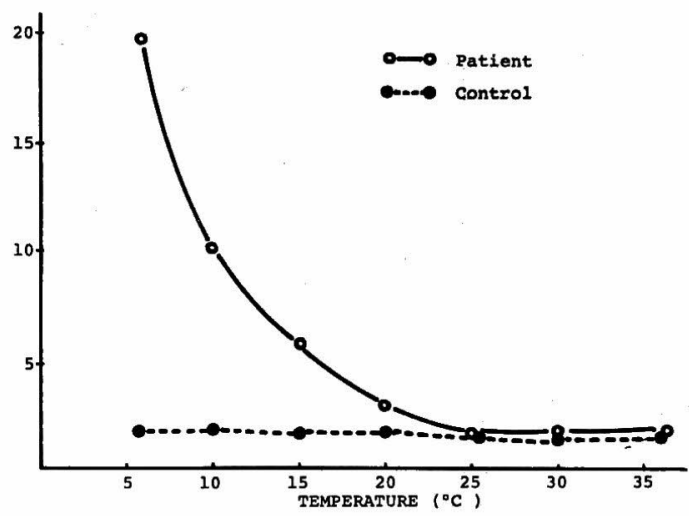

図 2. 患者血清の相対比粘度を示す.

貧血もなく肝機能検査にも異常はない，骨 $\mathrm{X}$ 線 所見でもpunched outなどの病的所見はなかつた が，骨䯣像には軽度のplasmocytosisを認め典型的 なflame cellが多数観察された，次に主な検査成 績を示す。

i）低温に括ける 患者血清の 相対比粘度の変 化；Ostwald粘度計を使用し温度条件を変えな がら蒸留水に対する相対比粘度を測定した（図 2 ). $4{ }^{\circ} \mathrm{C}$ では比粘度 20 の結果を得た. 次に, 患者 血清を $4{ }^{\circ} \mathrm{C} に 2$ 昼夜保存した後, $4{ }^{\circ} \mathrm{C}, 20,00 \mathrm{crpm}$ 30分間の遠心操作を加えcrude IgA cryogelを分離 し, これを生食水 $\left(20^{\circ} \mathrm{C}\right)$ に溶解した後 $4^{\circ} \mathrm{C}$ に 1 昼 夜静置し再び $4{ }^{\circ} \mathrm{C} 20,000 \mathrm{rpm} 30$ 分間遠心 Lcryogel を得る。この操作を 3 回反復してcryoglobulinを 純化した。この間にcryogelの収量は次第に減少 した. 純化したcryogelは $4{ }^{\circ} \mathrm{C}$ 内で約 2 分間で完全 に凝固し， $37^{\circ} \mathrm{C} に$ 加温すれば透明液状になつた。 純化すると室温でも容易にcryogel化している. 本例のcryoglobulinはgelatinousな状態でみられ， precipitateの状態は一度も観察されなかつた．

ii ) cryoglobulinの免疫学的検索；原血清, 純 化cryogelの免疫電気泳動像を図 3 に示す. 検出さ れたM成分括よび純化cryogelはIgA-ג型で，他の 抗血清とは反応せずIgA単独から成るcryoglobulin であることが判明した。 cryoglobulin除去前後の 血清IgAを測定しIgAのうちIgA cryoglobulinの占

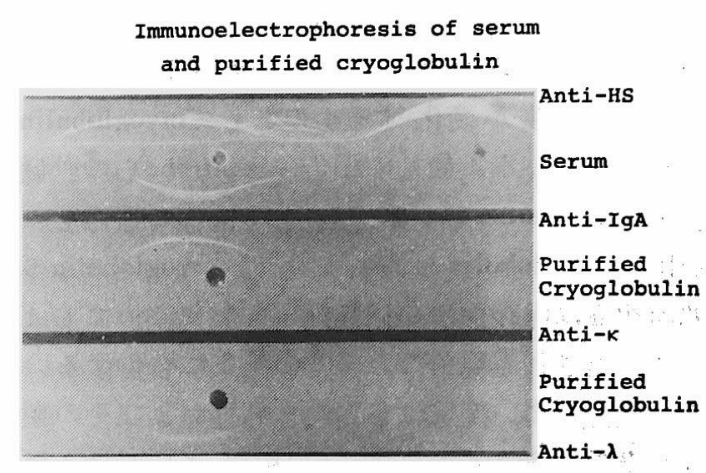

図 3. 患者血清および精製cryoglobulinの免疫電気 泳動像を示す。

Ultracentrifugation of CRUDe CRYOglobulin

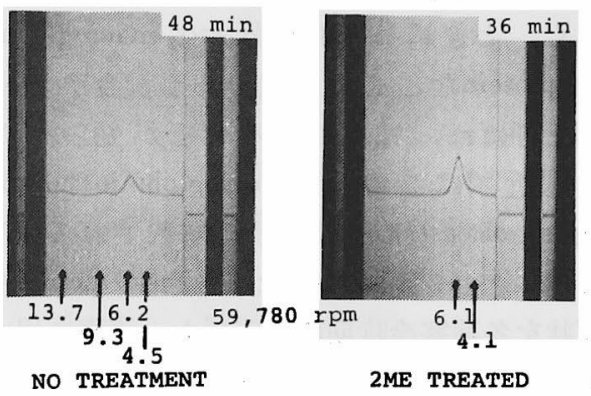

図 4.Albuminを少量含有するcryoglobulinの超遠心 分析像を示す. 左は $2 \mathrm{ME}$ 処理前, 右は $2 \mathrm{ME}$ 処理 後の分析像である。

める割合を測定すると $48.8 \%$ であった．この精製 IgA cryoglobulinは原血清と同一の 条件で泳動し ても易動度を異にしていた。このcryoglobulinは 2 ME (mercaptoethanol) およびGSH剤で処理す るとその性格を失なつた。濃縮した尿，唾液中に も IgA cryoglobulinを認めた。

iii）沈降係数の測定；少量のalbuminを含む IgA cryoglobulinを59,780rpmで超遠心分析する と図 4 に示寸様に6.2 S，9.3 S , 13.7 S Kpeakを 認め, polymer IgAの存在を確認した.このpolymeric IgAは2 MEの添加によりmonomer ( 6.1 S ）に移行した.

iv）骨䯣像；May-Giemsa染色標本では 5\% のplasma cellを認め (図 5 ), flame cellやgrape cell様細胞も散見されたが，骨髄腫を思わせる悪 


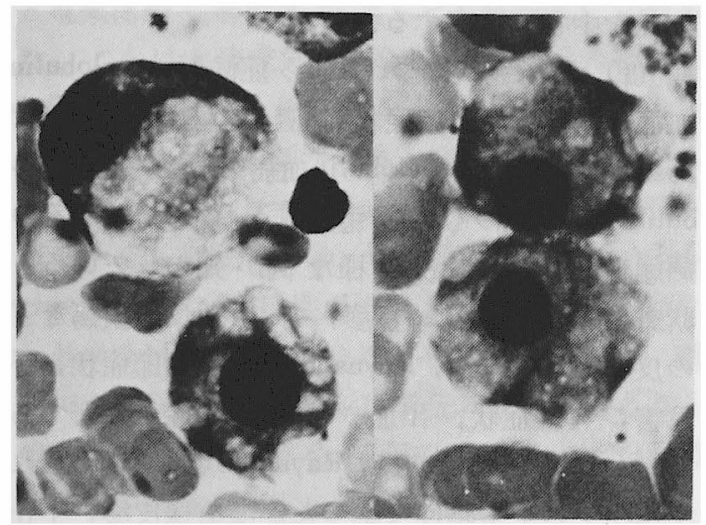

図 5，骨嗔形質細胞像を示す，胞体はきわめて大き くsignet ring cellのよ5に見える細胞やgrape cell 様細胞も認める. 大型で 25〜 $40 \mu$ にもおよょ. $(\times 100)$

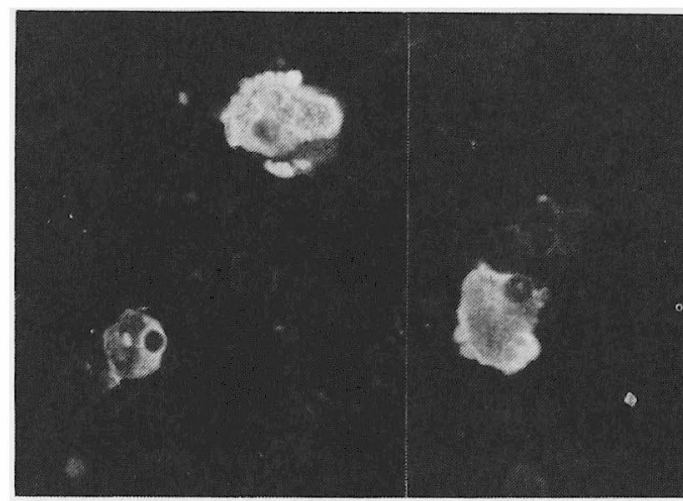

図 6，FITC標識抗ヒトIgA抗血清で染色（直接法）

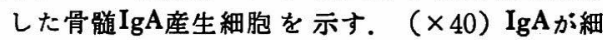
胞膜より放出される様子が明らかである。

\section{PLETHYSMOGRAPHY}

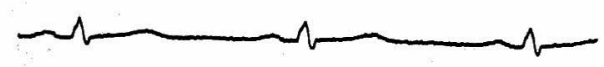

SECOND FINGER (R)
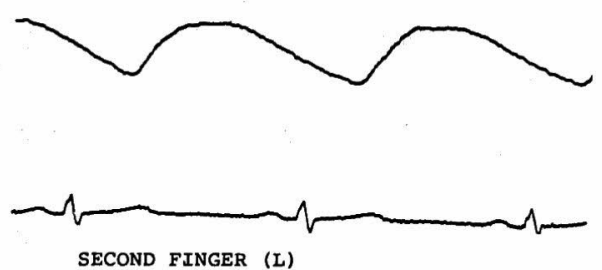

SECOND FINGER (L)

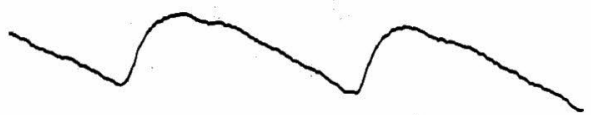

図 7. 指趾の脈波を示す，循環障害を認める（冬期に検査したもの）.
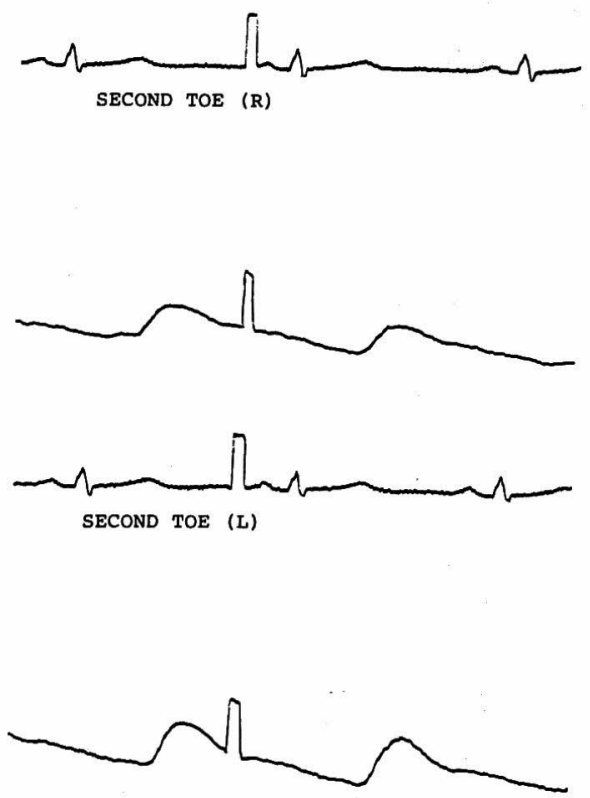

性所見は観察されなかつた。骨髄IgA 産生細胞を FITC標識抗ヒトIgA抗血清で直接法で染色する と（図 6) 極めて大型 $(25 \sim 40 \mu)$ の細胞が大多 数を占め, 大きな胞体の中に顆粒状のIgAが観察 された.この標本をMay-Giemsaで後染色し 全形
質細胞に対するIgA含有細胞の占める割合を算定 すると $38 \%$ であつた。

v）指頭脈波；左右差はないが，全体に低電 位で立ち上りが悪く（図 7), 循環障害のあるこ とを示唆したが, GSH凧, 副腎皮質ホルモンの投 


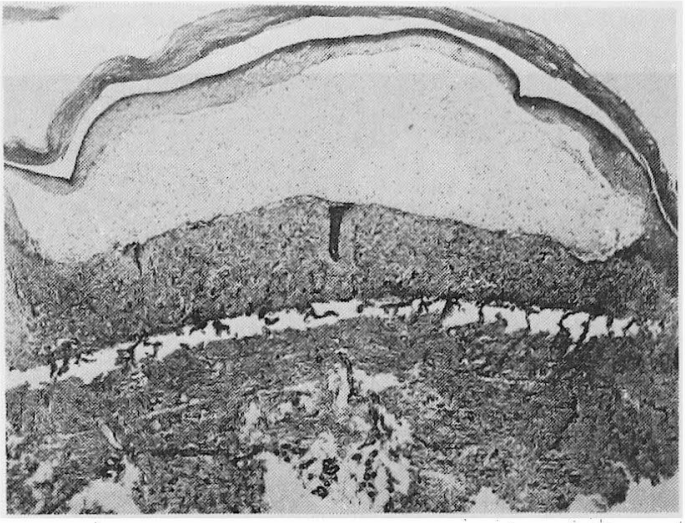

図 8. 皮膚組織のH-E染色像. 大き水泡形成を みとめ，血管周囲細胞浸潤は中等度であつた。

与によつて皮膚病変のみならず指頭脈波所見も著 しく改善された。

vi）皮膚生検の組織学的所見; 生検は足背に 生じた新鮮な水泡形成部分で実施した. 図 8 に示 すように大きなsubepidermal and intraepidermal bullaeを認め, 中には好中球, リンパ球が多数認 められた. 水泡下層にはリンパ・組織球浸潤のあ る肉芽組織が観察され，中等度の血管周囲細胞浸 潤を認めた。蛍光抗体法では抗IgAで特異的に染 色されるintravascular depositsは証明されなかつ た。

\section{考 案}

Thermoproteinのうちcryoglobulinは臨床症状を 惹起する点でより注目されている。初めて記載さ れたのは1933年に発表されたWintrobeらの骨䯣腫 例 ${ }^{1)}$ で, 以来cryoglobulinの物理化学的, 免疫学的 検討にかんする報告は少なくない. cryoglobulin が血清中に証明される場合, 基礎疾患のない本態 性のものと, 基礎疾患のある症候性のcryoglobulin とに大別され，前者はより少ない，通常cryoglobulinは注意深い観察により $4{ }^{\circ} \mathrm{C}$ に保存された血 清中に希ならず発見されるものである. Lernerの 報告では $4{ }^{\circ} \mathrm{C}$ 以下に保存した 121 例の血清を詳細 に観察した結果, 微量のcryoprecipitateを含めて 35例 (29\%) 飞確認出来たと述へてている3). 本症例 をもとにcryoglobulinにかんする近年の免疫学的
知見を中心に考察する.

（1）臨床症状について：症候群cryoglobulin 血症では，その臨床症状は個々に極めて多彩で あるが, 本態性cryoglobulin血症を含めてcryoglobulinの存在そのものが惹起する症状には, その 病態生理の面から次の様な例が 知られている. 紫斑, 寒冷䕒麻疹, 丘疹, 水疮, 皮膚潰瘍など の皮病病変のほか, Raynaud現象, 関節症状, 腎 障害, 神経症状, 出血や小動脈血栓症などであ る4)5). 本症例では紫斑, Raynaud現象は認められ ず寒冷テストす陰性であつたが涷瘡様皮疹, 小丘 疹, 小水疮, 浅在性潰瘍の形成が顔面, 耳染, 四 肢の露出部位に観察された。これらの皮病病変は 気温の上昇とともに自然に治瘜し, 軽度の色素沈 着を除けばほとんど郎痕す残さず消失した．皮唐 病変部の生検組織検査では細胞浸潤をともなつた 大きな水泡形成と血管周囲細胞浸潤が観察された が血管内hyaline depositsや蛍光抗体法でFITC標 識抗IgAによつて特異的に染色される血管内物質 は証明されなかつた. 皮痛病変とIgA-cryoglobulin の直接の因果関係は証明されなかつたが，本症例 では冬期でも副腎皮質ステロイドやGSH剂による 治療が皮痛病変に奏効したことは両者が密接に関 係していたことを示唆する。

（2）免疫化学的知見： 諸家の報告4) -8)をも とにcryoglobulinをその組成から表 2 のように分 類した。このうち骨髄腫などに合併する I 型cryoglobulinは精製されると，免疫電気泳動で原血清 の示すM成分と同位置に同じ形の 沈降線を形成 し， $\mathbf{L}$ 鎖の型も一致するのを原則としている．II 型の場合にはM-bowの形成はなく $\mathrm{L}$ 鎖は $\kappa$, $\lambda$ 両型 を示す．本例の I 型IgA cryoglobulinは精製する

表 2. Cryoglobulinの分類

\begin{tabular}{lll}
\hline Type I & Monoclonal cryoglobulin & $\begin{array}{l}\text { IgG } \\
\text { IgA } \\
\text { IgM } \\
\text { Bence Jones prot. }\end{array}$ \\
Type II & $\begin{array}{l}\text { Mixed cryoglobulin with } \\
\text { a monoclonal component }\end{array}$ & $\begin{array}{l}\text { IgG-IgG } \\
\text { IgM-IgG } \\
\text { IgA-IgG }\end{array}$ \\
Type II & $\begin{array}{l}\text { Mixed polyclonal cryo- } \\
\text { globulin }\end{array}$ & $\begin{array}{l}\text { IgG-IgM } \\
\text { IgG-IgA-IgM } \\
\text { IgG-IgM-Complement } \\
\text { Igg-lipoprotein }\end{array}$ \\
\hline
\end{tabular}


と電気泳動で易動度が速くなりM-bow 変形し た.これは血清成分と結合しやすいIgAの特性と 無関保ではないと思われる。ところで 周知の如 く，M成分に抗体活性のある例が報告されている が,この現象はcryoglobulinにも認められ注目さ れている，例えばリウマチ患者に検出されたIgG cryoglobulinにRF活性が証明された場合がありの， これに2 MEを作用させるとその性格を失い，透 析で $2 \mathrm{MEを}$ 除去すると再び元の性格にもどり， 寒冷沈降性に-SS-結合が関与していることを示唆 し，その本体の解明に重要な知見を与えている。 またGreyらはcryoglobulinはimmune complexでは ないかといら疑問をいだき，7例のIgG骨髄腫 蛋白から成るcryoglobulinの抗IgG抗体活性の有無 をRA test, ${ }^{131}$ I標識正常とトIgGにcryoglobulinの $\mathrm{F}(\mathrm{ab})_{2}$ を混合したときのcryoglobulin $\mathrm{F}(\mathrm{ab})_{2}$ の沈 降係数の变化などを指標に検討し，5例に陽性所 見を得，IgG cryoglobulinの抗IgG活性はFab部分 にある事実を報告している(10)。この様なcryoglobulinの抗免疫グロブリン活性にかんする報告は 少なくなく，臼井ら ており，とくに混合型（II， III) cryoglobulinの 例に詳しい。例えば寒冷蓴麻疹例に証明された IgA-IgG cryoglobulinではIgAに抗IgG活性が判明 している し ${ }^{12)}$, 原発性macroglobulin血症に認めら れたIgM-IgG cryoglobulinではIgMに抗IgG活性 が証明されている゙8)。またPeetoomらのIgG-IgM cryoglobulin血症12例の詳細な分析では，正常な IgGを抗原とした場合このIgMとの間にLatex凝 集反応で12例，寒天内免疫扗散法で 12例， Rh抗 体感作赤血球凝集では8例に，モルモット補体と ヒト白血球を用いたimmune adherenceでは 6 例 に陽性を呈し，IgMに抗IgGの性格がありこれが 何らかの機作で寒冷時にのみIgG-IgM immune complexを作り沈降ゲルあるいはprecipitateを作 るのであろらと述べ，IgGに対する自己抗体で あろらと推論している ${ }^{16)}$. 臨床的にもこの種の cryoglobulinを持つ患者には何らかの自己免疫疾 患を思わせる症状が観察されることがある。たと
党ば，IgG-IgM cryoglobulin症例では，しばしば immune complexに䚻因する桷漫性系球体堅资と 思われる所見が観察される。その腎組織は蛍光抗 体法で抗IgG，抗IgM，抗 $\beta_{1} \mathrm{C}$ 抗血清で特異的に染 色され，一方，系球体に沈着した免度グロブリン と同一の蛋白がcryoglobulinにも証明されるとと むに血清補体価の低下むあり, immune complex glomerulonephritis と考えられている5゙.なおこの 様な補体成分を含む混合型cryoglobulinは $56^{\circ} \mathrm{C} 30$ 分間の加温により寒冷沈降量が著しく減少し, 補 体成分を添加すると再び回復することにより発見 されている.さらに松橋らのIgG-IgA cryoglobulin

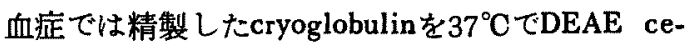
llulose columnにapply LIgGとIgAに分離すると

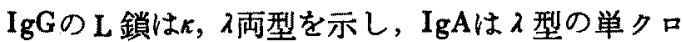
ーン性M成分でこれらの分画は単独では寒冷沈 降住を持たず，両者を混合するか或はこのIgAK 正常七トIgGを加えるとはじめて寒冷沈降性を示 ᄂ, Bence Jones蛋白，ウサキIIgG，ウマIgGを混 合してる寒冷沈降性はおきず，七トIgGに対して のみ特異的であつたと報告されている(15). Bluestoneらの報告 した 6 例中 4 例のIgG-IgM本態性 cryoglobulinにはDNA様物質と抗DNA抗体が証明 され，この抗DNA活性はIgMにのみ存在し，加え てIgMには抗IgG活性をわ検出されており興味あ る症例である ${ }^{16)}$ 。ところで本例のようにIgA単独 から成るcryoglobulin血症の報告は極めて少なく， これまでに骨髄腫に合併したものが数例知られ ているにすぎない(3)，精製 したヒトIgG，IgA， IgM，IgDをO型血球にcoat Lpassive hemagglutination㧊よびinhibition testで抗免疫 クロブリン 抗体活性の有無を本例の精製IgA cryoglobulin比 ついて検討した結果, これらの抗体活性は全く陰 性で， RF活性や寒冷凝集素などる証明されなか つた。 2 MEにはsensitiveでGSH郕を用いてもそ の寒冷沈降性は消失した，GSH剂（還元型glutathion) Кはin vivoでる有効性をみとめた．本例 は非骨䯣腫性疾患であるが，濃縮した尿，唾夜中 にもやはり cryogelが証明された。 cryoglobulinは 
血清以外にも証明され，関節液中に検出された報 告もある。たとえばCracchioloはRA患者21例の関 節液を観察し，血清中には証明されないcryoprecipitateが全例に検出され，IgG-IgM混合型12例， IgG単独 6 例, polyclonal IgG型 1 例, polyclonal IgM型 1 例， 1 例は $\pi$, 入両型の L 鎖のみから成る cryoglobulinであつたと述べている17.

（3）物理化学的知見：前述した様に寒冷沈 降に補体成分を必要とする例があるが，大部分の cryoglobulinは $56^{\circ} \mathrm{C} 30$ 分間の加温によつても影響

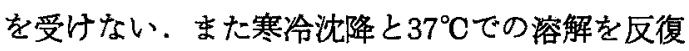
しても寒冷沈降性にはほとんど変化をみないが， 沈降量はこの反復操作によつて次第に減少するよ らに思われる。 cryoglobulinの寒冷沈降性にはそ の蛋白濃度む重要な関係を持つている゙118)，例兄 ばAlperらのdimer Bence Jones proteinから成る cryoglobulin血症例18)の 寒冷沈降性 は蛋白濃度依 存性で, $3.5 \mathrm{~g} / \mathrm{d}$ 以上の濃度を要している. 河合 らの例では $5.2 \mathrm{~g} / \mathrm{dl}$ 以上，臼井らの例11)では 2.8 g/a1以上ではじめて寒冷沈降している.一般には 蛋白濃度が高い程容易に寒冷视降し，かつ沈降開 始温度が比較的高いが，逆に蛋白濃度が高すぎる と沈降しない特殊な例む macroglobulin血症で証 明されている。本例の精製cryoglobulinは $30^{\circ} \mathrm{C} て ゙$ 約 20 分間, $4{ }^{\circ} \mathrm{C}$ 内であれば約 2 分間で寒冷凝固し た。年のほかcryoglobulinの寒冷沈降性はpHによ つても左右され, $\mathrm{pH} 5.5 \sim 7.0$ で最も大きく, $\mathrm{pH}$ 4.3以下や10.0以上では沈降しないことが知られ ている、イオン強度との関係に拈いても一般にイ オン強度が低い程寒冷沈降性は高く，イオン強度 0.4以上ではほとんど沈降を認めなくなる. Alper らの報告 ${ }^{18)}$ ではcryo-Bence Jones蛋白はpH 9.0で はイオン強度の低い程gel化しやすく,イオン強度 の高い程precipitateを形成しやすいと述べ，イオ ン強度の強弱によつて皮沈降状態に違いの生じる 点にも言及している. 次にin vitroでcryoglobulin の寒冷沈降性に大さな影響を与えるものに $2 \mathrm{ME}$, cysteineなどのSH化合物があるＩIgG単独から成 るcryoglobulinではこれらの薬剤による寒冷沈降
性の変化ははとんど認められないが，IgA型， IgM型，IgG-IgM混合型などではcryoglobulinの 性格を失らものが少なくない，透析でこれらの試 薬を除去すると再び寒冷沈降性を回復するようで ある、このことは-SS-結合によるdimerやpolymer の状態が， cryoglobulinの性格を有するための条 件の一端を負つていることを示唆していると思わ れる.そこでこの様なpolymerの存在を知る為に 超遠心分析が試みられ，多くの興味ある事実が 報告されている．例えばRF活性の証明されたIgG cryoglobulin例では $7 \mathrm{~S}$ のpeak以外に10 40 S K 渡る幅広いpeakが認められ，これを2 MEで処 理すると10〜15 S 隇り，RF活性は変化せずに cryoglobulinの性格のみが減弱したと述べられて いるし9., PrasadらのIgM cryoglobulin(例19)では $19 \mathrm{~S} か ゙ 70 \% ， 28 \mathrm{~S}$ と33Sが残りを占めたが，2 ME処理により寒冷沈降性が消失すると共に， 7 S が $85 \% ， 19 \mathrm{~S}$ が15\%を示す結果を得ている。 Ausherらの骨䯣腫(列防飞検出されたIgA単独から 成るcryoglobulinの場合には，6.75 S，9.5 S , $11.7 \mathrm{~S}, 13.4 \mathrm{~S}$ にpeakが証明され，cysteineを加え ると6.75 S のpeakは增大したが $9.5 \mathrm{~S}$ は影響を受 けなかつたと報告されている。本例でもpolymer の存在を確認し，2ME処理てpolymerの消失と $6.2 \mathrm{~S}$, peakの増大扰よび寒冷沈降性の消失をみ た.

その他にcryoglobulinの性格を解明するために， アミノ酸分析やcarbohydrateの含有量の測定が試 みられている。Zinnemanの報告したIgGが 型でIgMが 型であつたIgG-IgM混合型cryoglobulin血症例20)では，IgMがフミノ酸もcarbohydrateの組成 も正常IgM と全く同じであつたのに 対し, IgGKはsialic acidが全く欠如 Lhexosamine, hexoseは正常のわずか20\%しか含まれてい ず,このIgMには正常ヒトIgGを加えるよりも neuramidase処理でsialic acidを全く除去してし まつたIgGを加えた方がより寒冷沈降性を増した と述べこのことよりIgMはsialic acidを失なら 形で変化したIgGに対する抗体であろうと推論し 
ている

\section{結語}

これらの知見にもかかわらず， cryoglobulinの 寒冷沈降機構にかんする結論は未だ得られていな い.しかし種々溶媒中での寒冷沈降性, 超遠心分 析， $\mathrm{SH}$ 基の測定などから寒冷沈降性発現の 要因 Kpolypeptide鎖のfolding様式も問題になる一方, L 鎖のみから成るcryoglobulinの存在は寒冷沈降 にとつて分子の大きさは本質的因子でないことを 示し，むしろその沈降性は実は几 鎖にこそあるの ではないかと思わせる症例も発表され，次第に 本質の解明に近づきつつある. 将来はさらにIgD， IgEから成るcryoglobulin む発見され，その解析に 役立つむのと思われる。

\section{文献}

1) Wintrobe, MM and Buell, MV: Hyperproteinmia associated with multiple myeloma. With report of a case in which an extraordinary hyperproteinemia was associated with thrombosis of the retinal veins and symptoms suggesting Raynaud's disease. Bull Johns Hopkins Hosp 52: 156, 1933. -2) Lerner, $A B$ and Watson, CJ: Studies of cryoglobulins. I. Unusual purpura associated with the presence of a high concentration of cryoglobulin (cold precipitable serum globulin). Amer J Med Sci 214: 410, 1947. -3) Lerner, $\mathrm{AB}$ et al: Studies of cryglobulins. II. The spontaneous precipitation of protein from serum at $5^{\circ} \mathrm{C}$ in various sisease states. Amer $\mathrm{J}$ Med Sci 214:416, 1947. -4) Brouet, J-C et al: Biologic and clinical significance of cryoglobulins. A report of 86 cases. Amer J Med 57: 775, $1974 . \quad-5$ ) McIntosh, RM et al: Cryoglobulins. I. Studies on the nature, incidence, and clinical significance of serum cryoproteins in glomerulonephritis.
J Lab clin Med 75: 566, $1970 . \quad-6)$ Auscher, $\mathrm{C}$ and Guinand, S: Etude d'une $\beta_{2 A}$-globuline cryo-precipitable. Clin chim Acta 9: 40, 1964. -7) Meltzer, $M$ and Franklin, EC: Cryoglobulinemia-A study of twenty-nine patients. I. IgG and IgM cryoglobulins and factors affecting cryoprecipitability. Amer J Med 40: 828, 1966. -8) Grey, HM and Kohler, PF: Cryoimmunoglobulins, Seminars in Hematology 10: 87, 1973. -9) Melzer, $M$ et al: Cryoglobulinemia-A clinical and laboratory study. II. Cryoglobulins with rheumatoid factor activity. Amer J Med 40: 837, $1966 .-10$ ) Grey, HM et al: Human monoclonal $\gamma$ G-cryoglobulins with anti- $\gamma$-globulin activity. J clin Invest $47: 1875,1968 .-11$ ) 日 井美建子：Cryoglobulin 医学のあゆ及 62:947， 1967. -12) Wager, $O$ et al: Mixed IgA-IgG cryoglobulinemia. Immunological studies and case reports of three patients. Amer J Med 44: 179, 1968. -13) Bonomo, $L$ et al: Waldenström's macroglobulinemia with anti-IgG activity. A series of five cases. Clin Exp Immunol 6: 531, 1970. -14) Peetoom, F and Loghem-Langereis, E: IgM-IgG (M-7S) cryoglobulinemia. An autoimmune phenomenon, Vox Sang 10: 281, 1965. -15) Matuhashi, $T$ et al: $\gamma A-\gamma G$ mixed cryoglobulin. J J Exp Med 38: 205, $1968 . \quad-16$ ) Bluestone, $R$ et al: Detection and characterization of DNA in mixed (IgG-IgM) cryoglobulins. Int Arch Allergy 39: 16, $1970 . \quad-17)$ Barnett, EV et al: Cryoglobulinemia and disease. Ann Intern Med 73: 95, 1970. -18) Alper, CA: Cryoglobulinuria: Studies of a cryo-Bence Jones protein. Acta med Scand 179: 200, 1966. (suppl. 445). -19) Prasad, AS et al: Studies in macrocryoglobulinemia: Possible role of $\mathrm{SH}$ groups in cryoprecipitation. J Lab clin Med 69: 456, 1967. -20) Zinneman, HH et al: On the nature of cryoglobulins. J Immunol 100: 594, 1968. 